SF 503

.C74

Copy 1

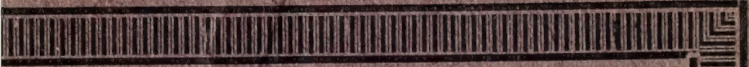

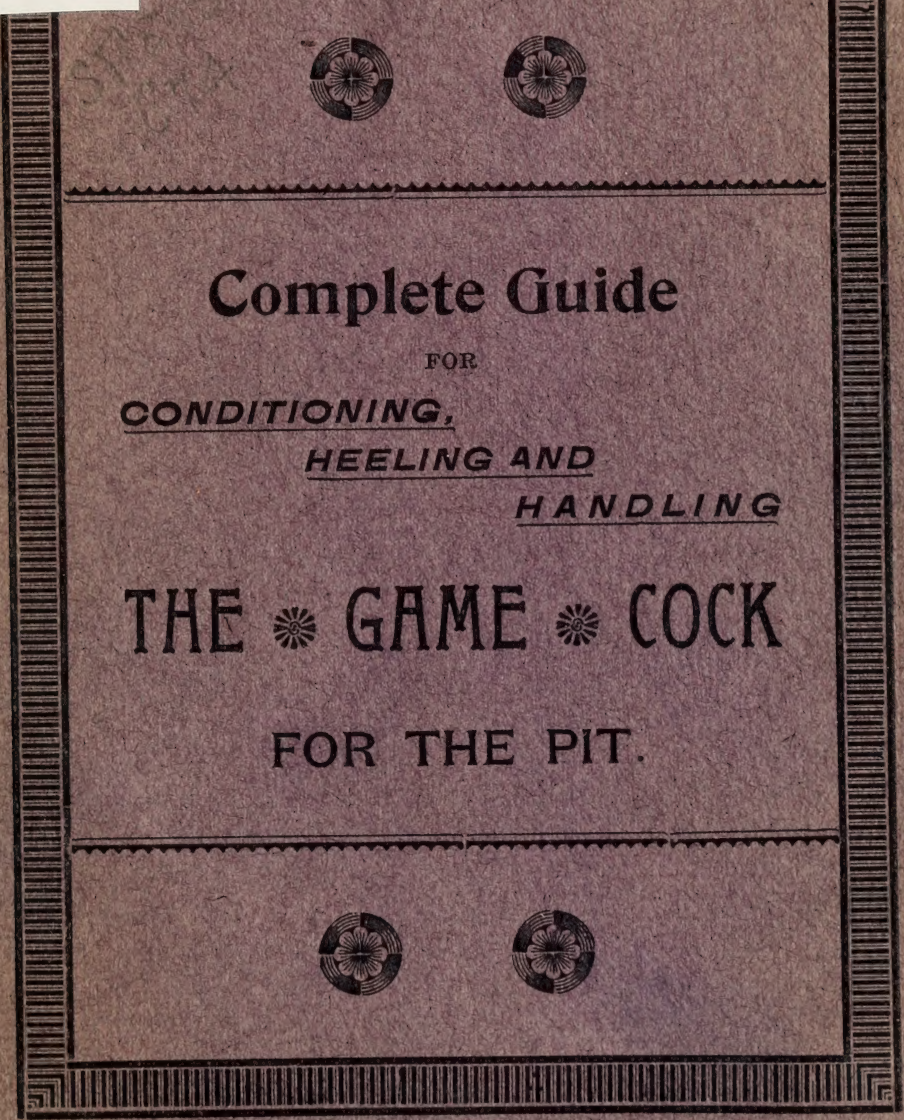




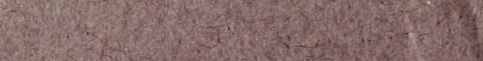

W.

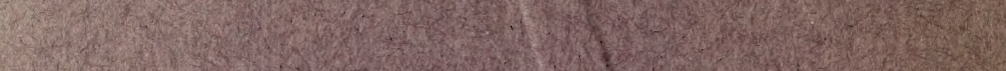

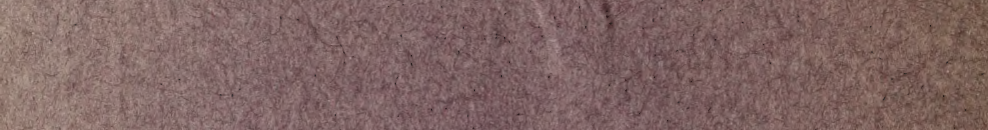

S. W. W. W. T.5.

W.

W.

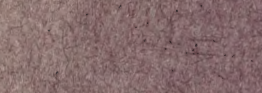

3.

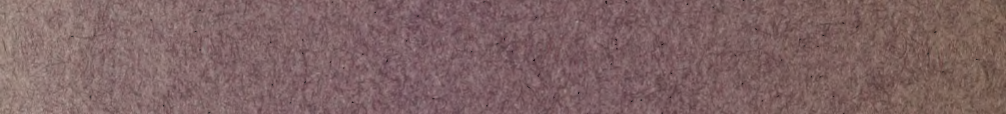

(2)

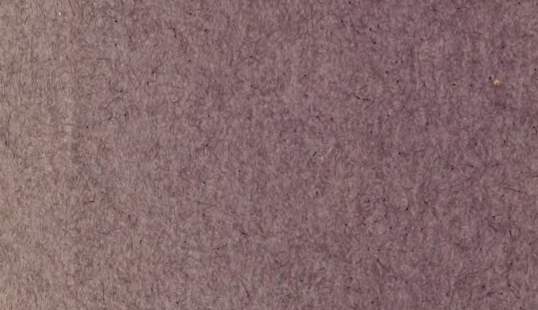

(i)

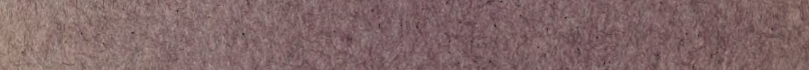

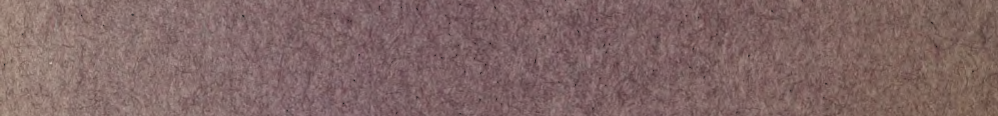

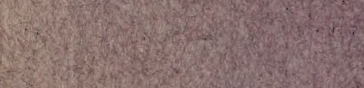

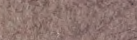

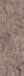

W. - 50 .

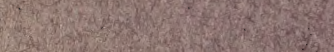

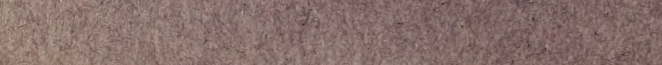




\section{COMPLETE GUIDE}

CONDITIONING,

HEELING AND

\section{HANDLING}

The - Game - Cock FOR THE PIT.

GEORGE CONDERMAN, M. D.

Hornellsville, N. Y.

Illustrated by Original Etchings.

PRICE ONE DOLLAR. $\square$ 
SECON YOPY, 1859.

SF50

DELIVERED TO

AUQ 301899

Library of Conger

40821

COPYRIGHT 1899 ,

BY GEORGE (jONDERMAN, M. D.

PRESS OF THE EVENIING TRIBUNE,

HORNELLSVILLE, N. Y.

46353 July 17.99. 


\section{INTRODUCTION.}

For years I have viewed with disfavor the tendency on the part of practical cockers to withhold from the traternity at large the principles and methoa's employed by them in conditioning, heeling and handling the game cock.

In the past, when it has been so difficult to obtain the necessary instructions in this line, the professional cocker may have been justified in guarding his secrets so zealously, they being his stock in trade, acquired as a iesult of years of experierce and at the expense of many a costly and expensive experiment.

Nevertheless, I believe it is for the best interest of those concerned in the advancement of this sport, that the correct principles be made public, thereby giving to the amateur the benefit of the experience of his elders, to the end that he may be relieved of the embarrassment attending the placing of his birds, money, reputation and peace ot mind at the mercy of some one who has a 
reputation as a heeler, but whose reliability is questionable.

The correct principles of conditioning and heeling are by no means as difficult of mastering as most old cockers would lead one to believe, yet there are a class of people so sadly deficient in confidence in their own ability as to be devoid of any tact or ingenuity, consequently they can never become successful heelers, and upon such the efforts of this book will be labor lost; but I trust to the amateur endowed with good common sense, who possesses the necessary contidence, and who will follow closely the instructions laid down iu this book, will be rewarded by becoming a successful heeler and handler of game cocks.

The mission of this book, therefore, is to give to the possessor the information I have been able to obtain, together with the benefit of many years experience, to the end that anyone who will practice my methods will soon develop the necessary dexterity enabling him to become his own heeler and handler. Trusting that my efforts will meet with the general approval of the fraternity at large, I am Faithfully yours,

George Conderman, M. D. 


\section{THE PIT.}

In constructing a pit you should strive to have it at least Iox 2 feet and about 18 inches high ; also arrange to have corners "blocked" or cut off, by placing a 10 or 12 inch strip firmly in each corner. Insist upon having it well lighted. Never fight in sawdust, dry earth nor shavings. Tan bark is the only bottoming, unless fresh earth is used.

\section{CONDITIONING APARTMENTS.}

Secure a good, warm, well lighted and well ventilated room, so that the temperature may be kept at about 60 degrees, not varying more than five degrees either way. As lamp light is required room may be darkened accordingly.

Insist upon a warm room tor heeling and fighting. Never use a cellar for a condition place, and prohibit smoking in conditioning apartments. 


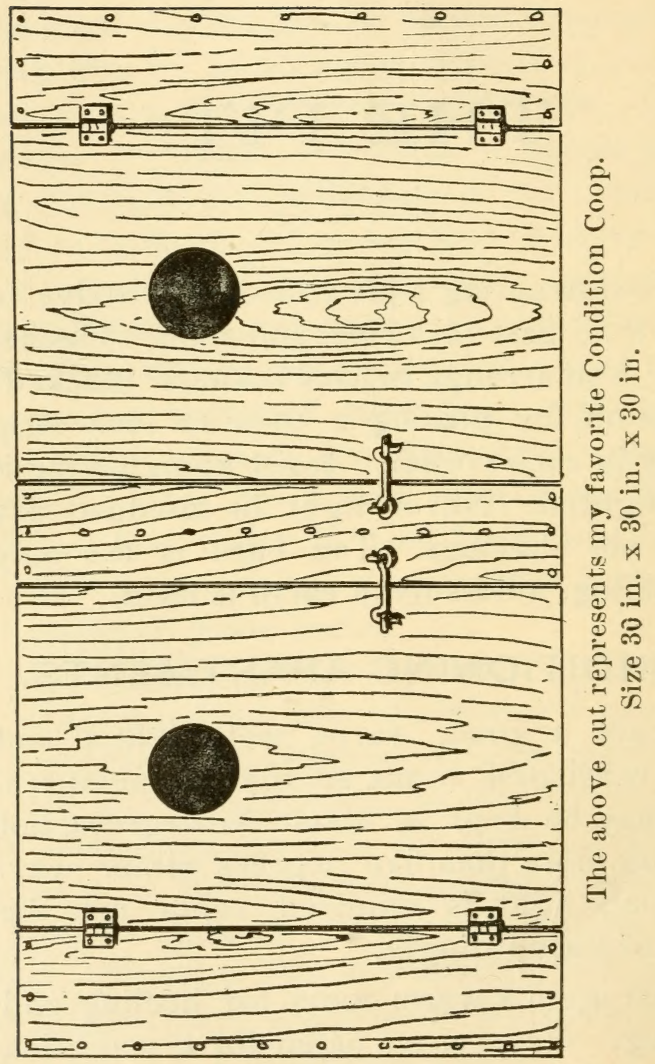




\section{CUTTING OUT COCK.}

In cutting out a cock, the first feathers to be trimmed should be the tail, leaving it not less than six inches in length; as much more as natural, so long as you cut square across the top. Next trim the feathers around the bottom of the tail called cock feathers, either in a straight or semi-circular line, according to taste; trim as near alike as possible on each side so as to present a neat appearance. Next trim the wings straight across, taking off no more than necessary in order to get a straight edge; both wings should be trimmed exactly alike as to length to insure the cock being evenly balanced when in battle.

The vent should always be trimmed. This should be done when cock is taken up for conditioning. It permissible enough superfluous feathers may be cut trom underneath wings and saddle feathers and around bottom of tail to slightly decrease weight, or if deemed advisable provided a cock is to be fought in warm quarteis.

The feathers around the comb and head are sometimes clipped closely to present a neat appearance and harmony with other extremity, insuring cleanliness and enabling 
the handler to more readily detect and judge the result of injury resulting from cuts about the head.

\section{HOW TO DISTINGUISH RIGHT AND LEFT HEELS.}

By clasping the leather of a heel between the thumbs and index fingers of both hands, the heel on a level with your eye and extending from you, by sighting through the socket you will observe that the point of the right heel will turn to your right and the point of the left heel will turn to your left; in other words, the points of the heels should always point towards the cock's head.

\section{EXERCISING.}

During the time allotted for conditioning, it is essential that cocks be tossed or flirted in order to develope wind and muscie, also to improve the steadiness of the bird as well as the disposition. It is therefore necessary that you handle your birds as gently as possible; by so doing you are benefited in the end by noticing that such caretul exercise has been the result of careful treatment, and 
your birds will be coor, gentle and collected throughout their battle.

Cocks should be tossed on a soft blanket or cushion well padded with straw or hair. Throw your birds up about two feet from cushion, in such a manner that they will strike directly on the cushion each time in alighting. This is done by catching the bird with both hands closely around the wings, allowing your fingers to protrude under each wing, but rlo not clinch or squeeze the bird in the least; throw him in the air about two teet, letting him strike on the cushion; grasp him again gently and toss again, repeating until bird shows signs of breathing; this will be enough for the first day. Increase the work gradually each day until satisfied he has sufficient wind and muscle. Atter two or three days it is excellent exercise to walk a cock back and torward on a long cushion until he regains his breathing alter prolonged flirting.

As an advantage in determining fighting qualities of a bird it is well to spar birds during conditioning, by the use of muffs tied on the bird's legs and letting him fly for a few minutes. This will enable you to 
closely observe as to the cock's peculiarities, also being an excellent exercise and relief from the strain and tedious course the bird is undergoing. Sparring once during conditioning is sufficient and should be indulged in about the tenth day, in the evening. Atter sparring examine closely to be sure no injury has been inflicted, bathe and dry birds and retire them for the day.

\section{EXERCISING A VICIOUS COCK.}

The simplest and best method perfected to enable one to train a vicious cock to give in $t \cap$ nrdinary methods of being handled, is to sut into a pit, if you fortunately can afford one, if not a room suitably strewn with tan bark as a bottoming. By drawing the attention of the cock you are conditioning to a bird you have in your hands he will fly all over the room atter the bird. In this way he will not only get the best of exercise but will be taught to strike his opponent in any part of the body, not waiting to find the head, which has cost many a cock his life.

\section{METHOD OF CONDITIONING.}

Many methods have been advocated for conditioning, each considered by its author 
as the best, yet the majority differing but little in a few minor points. As it would be impossible for me to give you all the known methods and, on the whole, would only have a tendency to confuse, I will minutely describe to you my favorite method, which I believe possesses as much merit as any and will yield perfectly satisfactory results.

Put your birds in condition coops, elsewhere described and leave without food for twenty-tour hours, but give all the water they will drink, examine carefully to see that they are in good health and feather, see that they are tree from vermin-if not "tallow" is one of the best exterminators that is not injurious to the birds-wash and dry the legs and feet, clipping off the longer feathers around the vent, carefully weigh with empty crop, making a note of each one's weight and also about how much you wish to reduce. If bird is very fat he will probably stand about eight ounces; if not, five or six ounces. Occasionally a cock will need to take on a few ounces to be at his best. These points can only be arrived at by experience and good judgment, which will tell you what you should consider proper fighting weight. 
If satisfied that you will fight the particular cocks you have, cut them out and cut their heels off one-half inch from leg, using powdered chalk to stop the bleeding. This should be pressed on the end of the stump with your thumb and held there for a tew minutes.

For those that are tat give a pill to each, composed of ten grains of cream of tartar mixed in butter. In about an hour feed bread and milk all that they will eat; then flirt or toss a tew times to start physic. In a few hours you may give a little toast moistened with water or milk.

\section{THIRD DAY.}

In the morning give a few dips of raw eyg and feed of wheat. In the evening give cracked corn, flirting twice through the day, about forty tosses each time, giving water twice, about four dips each time.

FOURTH DAY.

In the morning give a feed of dry "corn bread " (made according to receipt elsewhere given). In the evening feed wheat, exercising the same as previous day. Water twice, about four dips each time. 


\section{FIFTH DAY.}

In the morning feed cracked corn. In the evening feed either corn or wheat, giving half of hard boiled egg to each. Water twice, about four dips each time.

SIXTH DAY, SEVENTH DAY, EIGHTH DAY.

Feed same as fitth, increasing work to 60 or 65 tosses.

\section{NINTH DAY.}

In the morning feed pearl barley and give barley water to drink. At noon feed a little lean beef, chopped fine. Work twice, increasing work to at least 75 tosses. In the evening give half of hard boiled egg and cracked corn.

TENTH DAY.

In the morning give half of raw egg to each and feed wheat; at noon a piece of sour apple. In the evening teed cracked corn discontinuing the wheat from now, as it may physic when you do not want it to do so.

ELEVENTH DAY, TWELFTH DAY.

Feed corn twice, morning and night; water twice always, but never more than 
five or six dips at a time, increasing work graduaily as they will stand it.

\section{THIRTEENTH DAY.}

It fought at night feed a little pearl barley or cracked corn and a few dips of water, a hour or so after feeding, exercising lightly.

Always handle your birds gently as possible, change straw in coop daily; allow them to become accustomed to lamp light, if to be fought at night; keep in a warm, well ventilated place.

\section{HEELING.}

The noted Dr. Cooper was among the first to lay down definite rules for heeling. These are generally known to the cocking world, and are as follows:

"Let your bird be held by a competent person so that the inside of leg is perfectly level; cover the spur with a piece of damp kid so as to get the socket of the gaff to fit tightly and prevent its turning or shifting. Then take your thumb and torefinger and work the hind toe of the cock; while doing this you will see the leader of the leg rise and fall at the upper joint of leg. You will set the right gaff on a line with the outside 


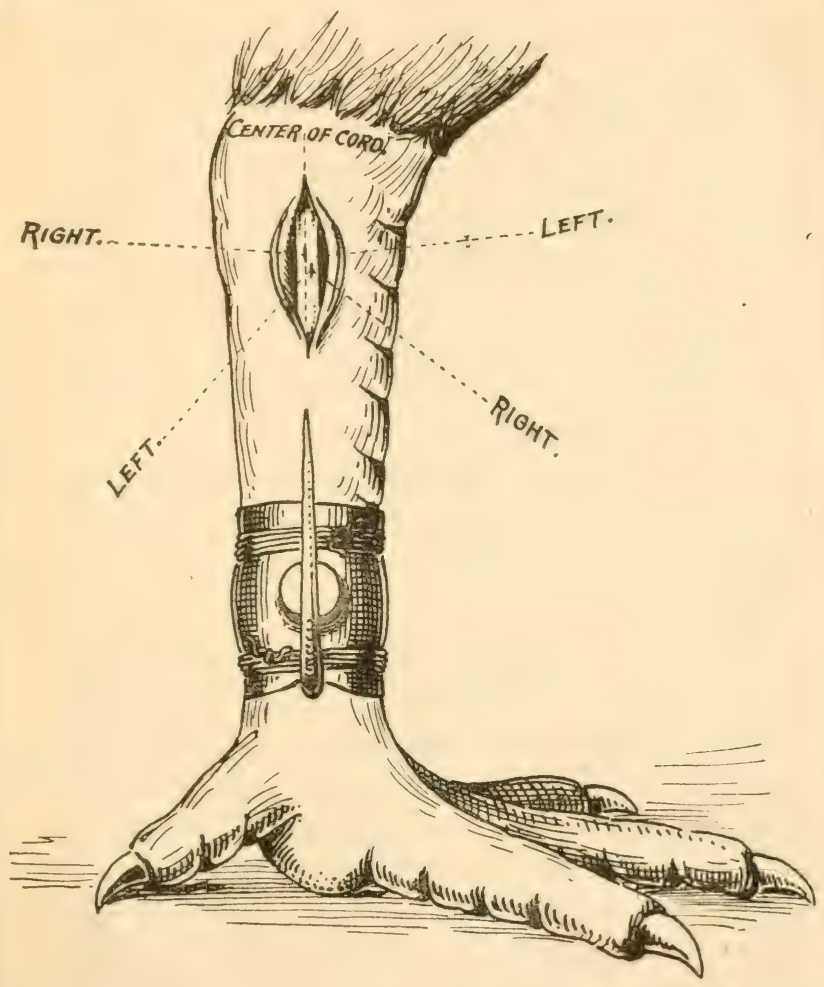

The above cut shows the relative points on the cord which are the guide for the proper setting of the heel. Those on the left of page show where a head aud aeck hitting cock should be heeled, those on the right a shuffling cock. 
of leader at the upper juint, and the left gaff you will set on a line with the inside of leader at the upper joint. Be carelul not to set the point too far in, as it would cause the cock to cut himselt. When you have the gaff arranged properly, tie it with good wax ends, but not too tight as to cramp the legs or toes. After the gaffs are tied on wet your fingers and pull the cock's toes so they will not be cramped."

The method of Dr. Cooper is amongst the most popular cnes at this day, a large percentage of cockers fatthfully adhering to the same.

Grist in his "Keep" modifies the method of Dr. Cooper in that he directs that the right gaff should be set on a line with the outside of leader at the upper joint, and the left gaff (instead of on a line with the inside of leader advised by Dr. Cooper) he sets oneeighth of an inch farther out than the right gaff. This method is advised for one and onequarter inch up to two inches for day fighting.

If for night fighting, he directs that the right gaff be set on a line with outer edge of leg, and the left gaff one-eighth of an inch farther out. 
You will notice that in both these methods no distinction is made as to the fighting peculiarities of the cock heeled, as for instance you may have a purely head and neck hitter, known as a breaking fighter. You may have a shuffling cock that may be a high or low shuffler, or you may have a mixed fighter.

Although I dislike to differ from the excellent authorities quoted, it has always been my belief and experience that cocks should be heeled in keeping with their fighting peculiarities, which peculiarities should invariably be ascertained by sparring the cock, carefully noting the same and heel him accordingly.

Upon this theory I shall proceed to de scribe to you minutely my method, for which I not only clam scientific principles but practical results.

In the first place, the cock should be in perfect readiness to ight; that is, cut out, his heels having been previously sawed off one-halt inch from the leg. 


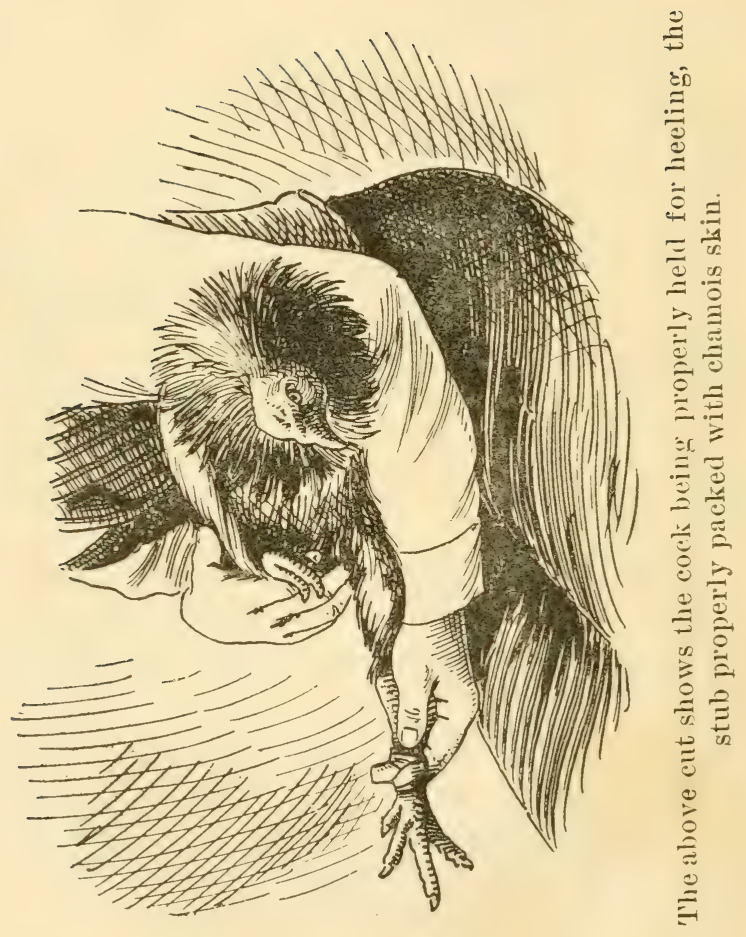


Chamois skin strips, windings and packing should all have been carefully selected and close at hand, in order that the cock will not have to be held in a cramped position for a longer time than is actually necessary.

See that you have perfect light and are comfortably seated. Choosing the one you consider most competent to hold the bird, you have him seated directiy opposite you and direct him how you want the cock held.

It the right heel is to be heeled first, instruct the holder of the bird to put both knees close together, laying the cock on his right side in the lap of the holder, his right arm being uncler the right wing, clasping the shank of the right leg with his thumb and middle finger, allowing the index finger to extend underneath the shank toward the toes on the under side. This is done as support to the leg while heeling.

The leg should not be raised nor lowered nor held too tightly. The chamois skin strips having been selected, being one-half inch in width, any length desired unless restricted, a small loop-hole should be cut about one-half inch from the end of each of the long strips. You should also have two 
short strips about two inches in length; lay on a short strip lengthwise of the leg, drawn over the stub of the spur; grasp the leg on the under side, holding one end of chamois down with your thumb on the upper side, instruct the holder to do likewise at the other end of chamois strip; place the slit in end of long strip over the short one and over the stub, drawing down to the shank, making one wind around the shank and over top of stub; then make one wind on upper side and wind below, place the heel on the stub to see if a good fit is obtained; if not, make it so with another short strip, until a perfect fit is obtained, winding above and below until the long strip has been exhausted, allowing one more wind below than above, watch closely that a good, clean, perfect wind has been made to insure a good foundation for heeling.

Place the heel upon the stub with the right hand, supporting the cock's leg with the left hand, draw both ends of the leather between the left hand supporting the leg.

With the right hand you work the hind toe backward and forward to enable you to locate the cord at the upper joint. The 


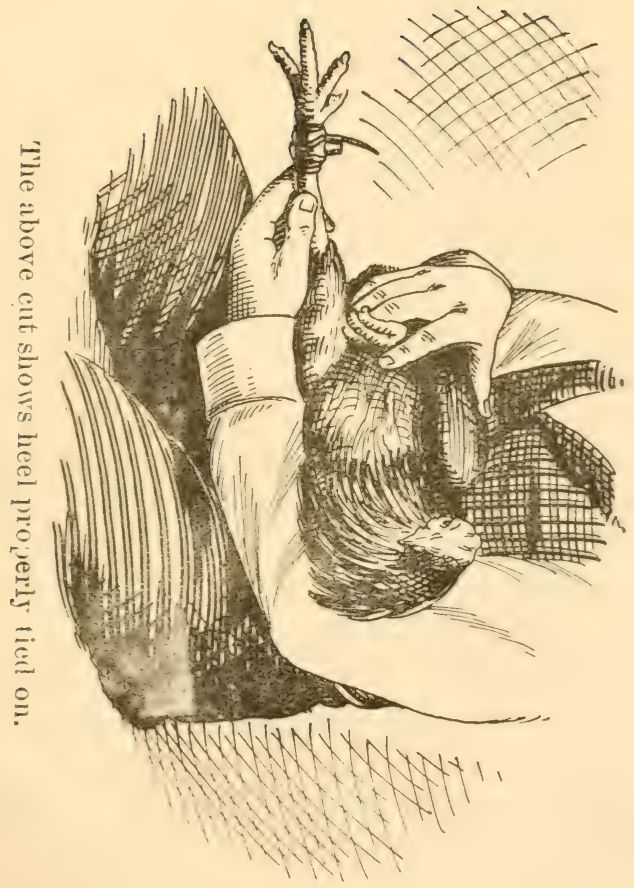


right heel is now on the right leg; draw the heel on cord and hold again with left hand, working the toe again, locate the center of cord, to which point you draw the point of the heel; this being done, be caretul not to move the heel while drawing leathers closely around the windings, ask the holder to allow his index finger to hold the leathers in place.

Taking up the wax-end, ascertain the center; first wind below the heel, once around, then above, once around; winding below again you will bring the strings to the top, making a loop around the blade at the top of socket with each string, then down again on the same side, and continue to wind above and below until satisfied that heel has been sately tied.

Be caretul not to wind too tight so as to compress or cord the cock's leg; the toes should be carefully pulled; then by placing the cock on a round perch, as a broom handle supported on edge of chair or table, if cock is able to grasp the same readily with his toes you may be assured he is not corded.

The above method of adjusting and tying on the heels should always be carefully carried out. 
The left leg should be heeled by having the cock held in the same manner, but of course turned upon his left side, supporting the leg to be held same as before, the holder holding his right forearm over the right wing and holding carefully between the fingers of the right hand the heel which has just been tied on, drawing it closely to the cock's side, so as to prevent his cutting himself should he ștruggle while the other heel is being tied on.

The left leg should be heeled as follows: Keep well in mind the center of the cord upon which you set the other heel, which you will again locate by working the hind toe. Now determine the middle distance between the center of the cord and the inside edge of cord; set your lett heel directly on this point, carrying out the same method of packing and tieing advised for right leg.

You have now heeled perfectly a cock for head and neck hitting, by some called a breaking fighter.

For a shuffling cock the above instruction differs but little, but you should be cautious to observe and bear in mind their importance $i$ n the cutting qualities which will be produced 
The right leg for a shuffing cock is to be heeled by setting the point of blade midway between the center and inner edge of cord, the left heel to be set on the inner edge of cord but no farther.

If the cock heeled is a high shuffier, heel him the same as a head and neck hitter. Invariably all game cocks strike closer with left leg than with right. Should it be noticable that the right stub sets higher on leg than the left, you will know that the cock strikes closer with right foot; in that instance the heeling should be reversed according to the style of fighting produced by the cock. 


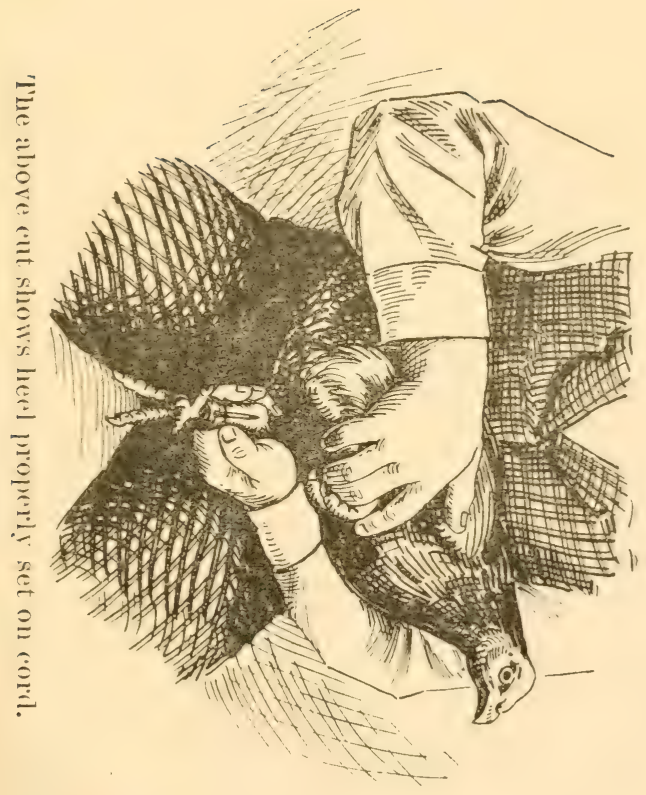




\section{PITTING.}

To become a successful pitter, one must never loose his head in a fight. You must be able to watch every movement of not only your own bird but that of your opponent also, and must possess an eye that can calculate to a certainty the damage your own bird has received as well as inflicted, enabling you to take advantage of all or any rules that will allow you to be the aggressor or take advantage of any point they may afford, as for instance, by the clever foresight of a handler he may allow his opponent the opportunity to foul when such a chance is in store, but should be very reluctant and alert that such chance may not be strewn in his own pathway.

The pitter of a cock can only handle under the rules prearranged for the battle, as when hung either in himself or the web of the pit or when it may become necessary to give a cock his wing, being very careful as to only this much being done, and that such permission is stipulated in the rules governing,

After first billing of cocks, and permission having been given by referee allowing the battle to proceed, a handler should always 
maintain strict punctuality, seeing that his bird is always down on the score on time, being always ready and cautious when the term "handle" is called by referee, to be alert to respond to separate eocks quickly and tairly.

Always comply strictly and faithfully with the above, know the rules thoroughly, so as to improve every advantage permissible, yet take no chances of fouling.

A neat and clever handler will always be possessed of a small vial of witch hazel or other wash, as may be selected by himself, and soft sponge to properly nurse his bird between pittings, if allowed by rules governing.

Never fail to replace the wings to their natural position, enabling a cock to produce whatever speed he may possess.

If rules will permit, never fail to clear the throat of a groggy cock as often as necessary during time allowed for nandling. Quick and active handling at the proper time may enable one to prevent a cock's becoming badly rattled or seriously injured about the head and neck.

Never fail to carefully examine eyes, keep- 
ing as clean as possible. It blinked, be careful in pitting to give the good side toward the opponent.

In some articles, hovering over your cock is considered unfair, even if permitted by the rules governing. Don't practice it, as it is a disadvantage and injury to your own chance of winning. Give your bird plenty of room. Careful handling during conditioning and pitting will protect yourself against one who is constantly hovering or trying to get mixed up with his own bird. Although often resorted to in sharp practice, a competent pitter and a well trained bird can protect himselt when judges are honest and capable. 


\section{VALUABLE RECEIPES.}

FOR CANKER IN MOUTH.-Use burnt alum Ireely after removing cankered tissue. It very severe case burn the affected surface with a stick of nitrate of silver every other day.

For CUTS AND BRUISES OR SORES of any kind, whitch hazel salve is one of the best preparations to use.

FOr Vermin.-Dust with insect powder and put a few drops of ol. sassatras around the vent.

FOR IVASH DURING CONDITIONING- Witch hazel is the most wholesome and strengthening of any to be used; is also a disenfectant. Can be applied with a small sponge-

A few drops of Spirits of nitre in a quart of water is a good thing for fowls out of condition.

For Rattles in the Throat.-A tea. spoonful of equal parts of vinegar and kerosene oil twice daily will accomplish as much as anything that can be administered. 
Douglass Fluin Mixture.-

Sulphuric Acid, one ounce,

Copperas, one pound,

Water, two gallons,

One tablespoonful of the solution to be used in six quarts of water.

Douglass Powder Mixture. - Equal parts of powdered

Rhubarb, Sulpher,

Charcoal, Capsicum,

Chalk,

Sulphate of Iron.

Ginger, Rosin.

Use about one teaspoonful in each feed of bread and milk while conditioning.

Old Fashion corn Bread.-

One fresh egg,

Salaratus, one-half teaspoontul,

Buttermilk, one cupful,

Cornmeal, two cupsful.

Flour, one tablespoonful,

Steam two hours in tight pail, then place in oven for twenty minutes. This is to be feed during conditioning on the morning of the fourth day.

For Bruises About the Head and Eyes. use hot water freely. 


\section{DONT'S.}

Don't tease a cock.

Don't dub your stags too early.

Don't spar a cock without muffs.

Dor:'t fight a cock out of condition.

Don't spar your cock too trequently.

Don't be atraid of too much light"in pit.

Don't allow stags to be bossed when walked.

Don't fight a stag until at least ten months old.

Don't think that games mature with equal rapidity.

Don't think that all birds similarly bred are equal fighters.

Don't let size nor color be your only guide in selecting your best chicks.

Don't condemn a bird because he will nou fight when out of condition.

Don't think by making a cock ugly you will improve his fighting qualities.

Don't be convinced that continuous inbreeding is.beneficial to your stock.

Don't fight a cock overweighted as the wheeling habit is not to be acquired. 
Don't fight a cock with broken wing or tail feathers, provided otherwise in condition.

Don't allow printers' 1 k to induce you to forsake a well-tried strain for an uncertainty.

Don't fight a cock in pin feathers, toes that have been frozen nor with cankered mouth.

Don't depend too much upon name, seek speed, endurance and aggressiveness at all hazards.

Don't put perches too high, nor use coal cinders in the coop, or your bird is liable to develope corns,

Don't allow a cock to spar on a floor nor smooth surface as great injury may follow in event of straining himself. 


\section{PIT RULES OF AMERICA.}

In several of the old books on cock-fighting it was the custom to devote page after page to the different sets of pit rules. Many of the sets were very similar and some exactly identical, yet all were given in tull. Sometimes the same set would be repeated under another name, and oftentimes the same thing would be told over and over again with very little variation. Now the writer has here attempted to arrange and condense the essential rules into a small space, so that they may be in a convenient, handy form, and still so thorough that a man may grasp the essential features of the whole outfit in a moment's time.

There are in the United States and Canada three distinct systems or plans of pit rules:

\section{THE NEIV YORK}

set and its variations, used in New York, New Jersey, and the New England States.

\section{THE SOUTHERN}

used in most of the Southern States east of the Mississippi.

THE NEW WESTERN

used in nearly all the balance of the states 
and also in Canada-by far the largest territory on the globe employing one system of pit rules.

\section{NEW WESTERN PIT RULES.}

I. The two pitters shall choose a timekeeper and a referee. It shall be the duty of the former to keep time between rounds, and notify handlers to "get ready" at twenty-five seconds, then call "time" at thirty seconds The referee shall pay close attention to the handlers and birds, and see that the following rules are strictly adhered to:

2. All birds under 6-4, weighing within two ounces of each other are matched, except stags and broken-bill and blinker cocks, which shall be allowed four ounces against sound cocks. Sound cocks weighing 6.4 and upwards shall be fought as shakebags and matched regardless of weight.

3. All gaffs shall be round from socket to point; no others will be allowed.

4. Atter the birds are heeled they shall be " eighed by the referee who will call out their respective weights. He shall also examine the birds' gaffs.

5. Upon entering the pit the handler shall let the cocks peck each other three or four 
times; they shall then step to their respective scores, (which scores shall be tour teet each way from the center), set their birds squarely on their teet and instantly release them.

6. It is no fight unless a blow is struck while both cocks show.

7. It shall be unfair for a handler to touch either cock except as directed by the reteree.

8. The referee shall order a handler to give his cock a wing when necessary, or turn a bird that is on its back. These directıons may be given only when the cocks are not touching each other.

9. The referee shall call "handle" whenever a cock is fast in his antagonist, in himself or in the pit, (except during a count, in which case the birds are not to be handled until the end of the count), also at the end of "counts" and "minutes," and at other times when necessary.

IO. The handler of the gaffed cock shall draw the heels, catching the leg of his opponent's bird below the hock joint. The bird must not be raised from the pit floor until atter the gaffs have been drawn.

I I. Thirty seconds is the time allowed in 
all handlings, time to commence as soon as the cocks are lilted off the floor of the pit.

12. Between pittings it shall be tair for the handlers to wash their birds' heads, give refreshments, and help their cocks in any other way possible, but they must be ready to pit promptly on call of time.

I3. As soon as one cock ceases fighting, the referee shall call to the handler of the fighting cock, "Mr. A., count;" whereupon that handler shall count ten in an audible tone. After being handled the cock shall be pitted ayain and so continue until three tens in all have been counted. After the third count and randle, the cocks are to be placed breast to breast on the center score, when the pitter having the count shall count twenty and the fight is ended in his favor.

I4. The count can be broken only by a peck or blow from the cock which is being counted out, or by the death of the cock having the count, or by that cock showing unmistakable evidence of wanting to run away, in which case the referee shall call "count broken."

15. It the cocks should both cease fighting at the same time, or should refuse to meet at the beginning of a round, the referee shall 
call for one minute's time, at the expiration of which the cocks are to be handled and again pitted. If they refuse to meet atter the second minute, they are to be handled and pitted again, until the expiration of the third minute, and then they are to be handled and breasted on the center score. And if they still refuse to fight at the expiration of one minute, a fresh cock is to be brought to the pit. If one combatant shows fight and the other does not, the battle is given to the fighting cock. If both fight or both retuse, it is a drawn battle.

I6. If both cocks die, neither having the count, the longest liver wins. It the cock having the count is dying and the other cock wanting to run, the former wins the battle even though he die before the expiration of the count.

I7. The referee shall watch all movements of the fight and confine the handlers strictly to the above rules. He may overlook what he believes to be an unintentional error, but must decide the battle against any handler who plainly and wilifully violates the rules. 


\section{NEW YORK RULES.}

I. The pit shall be circular in shape, at least eighteen feet in diameter and not less than sixteen inches in height. The floor shall be covered with carpet or some other suitable material. There shall be a chalk or some other mark made as near to the center of the pit as possible. There shall also be two outer marks which shall be one toot each way from the center mark.

2. The pitter shall select one judge who shall choose a reteree, Said judge shall decide all matters in dispute during the pendency of the fight, but in case of theirinability to agree, then it shall be the duty of the referee to decide and his decision shall be final.

3. Chickens shall take their age trom the the first day of March and shall be chickens during the fighting season.

4, It shall be deemed foul for any of the respective pitters to pit a cock or chicken with what is termed a foul hackle, that is, any of the feathers left whole on the mane or neck.

5. The pitters shall let the cocks bill each other three or more times, but this is not to 
be construed that the pitter of a cock has a right to bill with his opponent's cock for the purpose of fatiguing him.

6. No person shall be permitted to handle his fowl after he is fairly delivered in the pit unless he counts ten clear and distinct, without either cock making fight, or shall be fast in his adversary, or fast in the carpet or hung in the web of the pit or in himselt.

7. Any cock that may get on his back shall be righted again by the pitter, but not taken off the ground he is lying on.

8. Whenever a cock is fast in his adversary the pitter of the cock the spurs are fast in shall draw them out, but the pitter of the cock has no right to draw out his own spurs except when fast in himself or in the carpet, or in the web of the pit.

9. When either pitter has counted ten tens successivelv without the cock refusing fight or making sight, or on the two cocks being again breasted fair on their feet, beak to beak on the center score or mark, the cock refusing to fight shall be declared the loser on ten being counted. The pitters are bound to tell each ten as they count them, as follows: Once, twice, etc. 
Io. No pitter atter the cocks have been declared in the pit shall be permitted to clean their beaks or eyes by blowing or otherwise, or be permitted to squeeze his fowl or press him against the floor during the pendency of the fight.

I I. When a cock is pounded and no person takes it until the pitter counts twenty, and then counts nineteen or twenty and calls three times, "who takes it," and no person takes it, it is a battle to the cock the odds are on; but the pitter of the pounded cock has the right to have the pound put up that is tiventy dollars against one dollar. If this is not complied with the pitter shall go on as though there was no poundage.

I2. If a cock is pounded and the poundage is taken, and if the cock the odds are paid against should get up and knock down his adversary, then if the other cock is pounded and the other poundage not taken before the pitter counts twenty twice, and calls out, "Who takes it," three times, he wins, although there was a poundage before.

I3. It shall be the duty of the respective pitters to deliver their cock fair on its feet on the outer score or mark facing each other, 
and in a standing position, except on the fifth ten being told when they, the two cocks, shall be placed on the centre score, breast to breast and beak to beak in like manner. Any pitter being guilty of shoving his foot across the score, or of pinching or using any other unfair means for the purpose of making his cock fight, shall lose the fight.

I4. If both cocks fight together, and then both should reluse until they are counted out, in such cases a tresh cock is to te hoveled and brought into the pit, and the pitters are to toss for which cock is to set-to first. He that wins has the choice. Then the one which is to set-to last is to be taken up but not carried out of the pit. 'The hoveled cock is then to be put down to the other and allowed to fight while the judges, or one of them, shall count twenty. The same operation shall be gone through with the other cock, and if one fight and the other refuse, it is a battle to the fighting cock, but if both fight, or both refuse, it is a drawn battle.

N. B. This rule is rarely carried into effect, but any pitter can exact it if he think proper to do so.

I5. If both cocks refuse fighting until four, five or more or less tens are counted, the pitter shall continue their count until one cock 
has refused ten time, tor when a pitter begins to count he counts for both cocks.

I6. If a cock should die before he is counted out he wins the battle if he fights last. This, however, is not to apply when his adversary is running away.

17. The crowing or raising of the hackle of a cock is not fight, nor is fighting at the pitter's hands.

I8. A breaking cock is a fighting cock, but a cock breaking from his adversary is not fight.

19. If any dispute arises among the pitters on the result of a fight the cocks are not to be taken out of the fight, nor the gaffs taken off until a decision has been made by the judges or reteree.

20. Each cock within two ounces of each other shall be a match except blinkers, when they are fighting against two eyed cocks, an allowance from three to five ounces shall be made. When blinkers are matched against each other, the same rule to apply as in reterence to two-eyed cocks

21. All matches must be fought with heels, round trom the socket to the point, not exceeding one and a quarter inches in length unless otherwise agreed upon. Drop Sockets, 
Cutters, Slashers and twisted heels shall be considered foul.

22. Previous to heeling the cocks in fighting mains the four spurs of same pattern and size shall be placed together and the pitter shall toss for choice of them.

23. In all mains at the end of each battle the judges shall order the spurs to be chang. ed, i.e., the spurs of the winning cock must be placed on the loser's next fowl and changed at the end of each battle.

24. Any person fighting a cock heavier than he is represented on the match list shall lose the fight, although he may have won.

25. In all cases of appeal, fighting ceases until the judges or the referee give their decision, which shall be final and strictly to the question before them.

26. When a bet is made it cannot be declared off unless by consent of both parties, all outside bets to go according to the main bet.

27. Each pitter when delivering his cock on the score shall take his hands off him as quickly as possible.

28. Any person violating any of the above rules shall be deemed to have lost the match. 


\section{SOUTHERN RULES.}

Note. On the morning the main is to commence the parties decide by lot who shows first. It is to be remembered that the party obtaining choice generally chooses to weigh first, and consequently obliges the adverse party to show first, as the paity showing first weighs last. When the show is made by the party the door of the cock house is to be locked and the key given to the other party, who inmediately repairs to his cock house and prepares for weighing. There ought to be provided a pair of grood scales and weights as low down as half an ounce. ()ne or two judges to be appointed to weigh the cocks. Each party by weighing the cocks intended for the show, a day or two betorehand and having all their respective weights, would greatly facilitate the business of the judges. There ought to be no feathers cut or plucked from the cocks before they are brought to the scale, except a few from behind to keep them clean, and their wings and tails clipped a little.

2, As soon as the cocks are all weighed the judge, the writers and the principals of each party and as many besides as the parties may agree upon, are to retire for the purpose of matching. They are to be all even matches first, then those within one ounce, and after- 
ward those within two ounces; but if more matches can be made by breaking an even or one ounce match, it is to be done.

3. On the day of the showing, only one battie is to be fought. It is to be remembered that the party winning the show gains also the choice of fighting this first battle with any particular cocks in the mitch. Afterwards they begin with the lightest pair first and so on up to the heaviest, fighting them in rotation as they increase in weight. The first battle, too, will fix the mode of trimming.

RULE I, When the cocks are in the pit, the judges are to examine whether they are fairly trimmed and have fair heels. It all be right and farr, the pitters are to deliver their cocks six feet apart (or thereabouts) and re, tire a step or two back; but if a wrong cock should be produced, the party so offending forleits that battle.

2. All heels that are round from the socket to the point are allowed to be fair ; any pitter bringing a cock into the pit with any other kind of heels, except by particular agreement, forfeits the battle.

3. If either cock should be trimmed with a close, unfair back the judge shall direct the other to be cut in the same manner, and at the time shall observe to the pitter that if he brings another cock in the like situation, unless he shall have been previously trimmed, he shall forteit the battle. 
4. A pitter when he delivers his cock shall retire two paces back, and not advance or walk around his cock until a blow has passed.

5. An interval of-minutes shall be allowed between the termination of one battle and the commencement of another.

6. No pitter shall pull a teather out of a cock's mouth or from over his eyes or head, or pluck him by the breast to make him fight, or punch him tor the like purpose, under penalty of torfeiting the battle.

7. The pitters are to give the cocks room to fight, and not to hover and press on them so as to retard their striking.

8. The greasing, peppering, muffing and sooping a cock, or any other external application, are unfair practices, and by no means admissible in this amusement.

9. The judges, when required, may suffer a pitter to call in some of his triends to assist in catching the cock, who are to retire immediately when the cock is caught, and in no other instance is the judge to suffer the pit to be broken.

IO. All cocks on their back are to be immediately turned over on their bellies by their respective pitters at all times.

I $r$. A cock when down is to have a wing given him if he needs it, unless his adversary is on it, but his pitter is to place the wing gently in its proper position, and not to lift 
the cock; and no wing is to be given unless absolutely necessary.

I2. If either cock should be hanged in himself, in the pit, or canvass, he is to be loosened by his pitter; but if in his adversary both pitters are to immediately lay hold of their respective cocks, and the pitter whose cock is hung shall hold him steady while the adverse draws out the heel, and then they shall take their cocks asunder a sufficient distance for them fairly to renew the combat.

I3. Should the cocks separate and the judge be unable to decide which fought last, he shall at his discretion direct the pitters to carry their cocks to the middle of the pit and deliver them back to back, unless either of them is blind; in that case they are to be shouldered, that is, delivered with their breasts touching, each pitter taking care to deliver his cock at this, as well as all times with one hand.

I4. When both cocks cease fighting, it is then in the power of the pitter of the last fighting cock, unless they touch each other, to demand a count of the judges, who shall count forty deliberately, which when counted out, is not to be counted again during the battle. Then the pitters shall catch their cocks and carry them to the middle of the pit and deliver them beak to beak; but to be shouldered if either are blind as before. Then if either cock refuses or neglects to figh 
the judge shall count ten, and shall direct the pitters to bring their cocks again to the middle of the pit and pit as before; and if the same cock in like manner refuses, he shall count ten again and call out "twice refused," and so proceed until one cock thus refuses six times successively. The judge shall then determine the battle against such cock.

I5. If either cock dies before the judge can finish the counting of the law, the battle is to be given to the living cock, ard if both die, the longest liver wins the battle.

I6. The pitters are not to touch their cocks whilst the judge is in the act of counting.

I7. No pitter is ever to lay hold of his adversary's cock, unless to draw out the heel and then he must take them below the knee. Then there shall be no second delivery, that is, after he is once delivered he shall not be touched until a blow is struck, unless ordered.

I8. No pitter shall touch his cock unless at the time mentioned in the foregoing rules.

I9. If any pitter acts contrary to these rules, the judge, if called upon at the time, shall give the battle against him. 



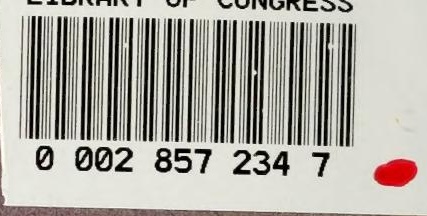

